\title{
Realidade e consciência nacional. O sentido político do modernismo
}

Daniel Faria*

\begin{abstract}
Resumo:
Este artigo tem como ponto de partida a crítica a uma temática recorrente na história da cultura da Primeira República: a da elite intelectual alienada, superficial. Esta imagem teve como um dos pressupostos o contraponto com o conceito de "modernismo", primeiramente em intelectuais como Tristão de Athayde e Rosário Fusco, elaborado a partir da crença na retomada da consciência sobre a realidade nacional. O paralelismo deste discurso com argumentos elaborados para dar legitimidade revolucionária ao golpe de 1930, no entanto, revela que os termos elaborados à primeira vista para a criação de um projeto cultural eram simultaneamente expressão de anseios políticos.
\end{abstract}

Palavras-chave: modernismo; realismo; política.

\section{Os embaraços da contextualização histórica}

Este artigo parte da perplexidade diante de um tema recorrente em trabalhos sobre a Primeira República. Tema entendido aqui não como assunto, e nem mesmo como perspectiva teórica, mas sim tessitura narrativa criada por conceitos e imagens. Trata-se aqui, sobretudo no campo da história cultural, da idéia recorrente de que escritores, artistas, engenheiros e mesmo líderes políticos viviam naquela época sob o signo da alienação, num mundo de superficialidade e futilidade. A relação desta memória com a construção da imagem do golpe de 1930 como revolução modernizadora do Brasil já foi suficientemente discutida pelos trabalhos de Edgar DeDecca e Carlos Alberto Vesentini. ${ }^{1}$ Seus fundamentos intelectuais e políticos mais abrangentes foram minuciosamente analisados em trabalho recentemente publicado por Maria Stella Bresciani. ${ }^{2}$ Mas diante disso o que se destaca é uma bibliografia pautada pela recorrência do tema referido.

Imagens de alienação ou leviandade na vida cultural da Primeira República estão presentes em trabalhos tão diversos como os de Marcia Camargos, Antônio Arnoni Prado, Jeffrey Neddell, em textos dedicados à obra de João do Rio, e já estava bem delineada nos estudos clássicos de Antônio Cândido e Brito Broca. ${ }^{3}$ Mas também estão 
implicadas no enigma historiográfico das nomeações e datações: diante de outros períodos localizados por designações bastante definidas, como a fase dita modernista após 1922 ou a própria "revolução" de 1930, a Primeira República pendeu para o adjetivo pejorativo "Velha" e no campo cultural prendeu-se à imagem de algo inacabado mediante o termo "pré-modernista". ${ }^{4} \mathrm{O}$ fato de tais nomeações terem sido majoritariamente abandonadas não significa necessariamente que as questões por elas colocadas foram resolvidas. Ao contrário, a imagem da elite intelectual, artística e politicamente alienada retoma o tema da ausência de projeto civilizacional, fundamento dos marcos históricos cristalizados na tradição moderna.

Para se pensar a perplexidade indicada, decidiu-se neste artigo pela retomada de um conjunto de textos hoje mais ou menos esquecidos que articularam esta temática à definição do significado do modernismo para a cultura intelectual brasileira. Principalmente trabalhos de Tristão de Athayde e Rosário Fusco, escritos entre os anos 1920 e 1940, dois dos pioneiros na articulação entre os lugares-comuns sobre a nacionalidade fora de si, a crítica da literatura da Primeira República e a definição de uma cronologia que se cristalizou como periodização canônica. Para além das questões de datação e nomeação aqui apresentadas, o que se pretende discutir é a base conceitual que fundamentou este modo de historicização. As idéias de alienação, futilidade, mundanismo e superficialidade têm como pressuposto o contraste com dois conceitos bem presentes nos autores dos anos 1920-1940, mas silenciados pela bibliografia mais recente: realidade e consciência (nacional).

Mas, antes da incursão nestes conceitos, vale mais uma observação sobre as nomeações e sua relação com a criação de imagens para os períodos da história. Em texto publicado em 1933, Tristão de Athayde dizia:

\footnotetext{
Vimos, da última vez, a figura de Hermes Fontes como uma das mais típicas desse período poético sem nome, que se estende do fim do simbolismo ao início do modernismo. Foi uma era de poetas sem escola, sem discípulos, sem imitadores, poetas sem trama poderíamos dizer, que urdiram individualmente os fios esparsos da ligação linear entre uma e outra época. Neles o engenho foi superior à criação. Foram habilíssimos manejadores de rimas e ritmos. Tiveram abundância de estro, riqueza de imagens, poder verbal. Mas não marcaram a sua época com um nome coletivo, tal e qual sucedera, um século antes, com os poetas que também fizeram uma ligação semelhante entre o classicismo e o romantismo. E o nome, parecendo um acidente sem importância, é quase sempre a expressão de uma realidade marcante e definida. $\mathrm{O}$ inominado é geralmente, ou mesmo sempre o indefinido. ${ }^{5}$
}

Hermes Fontes, escritor sem estilo próprio, seduzido pela beleza superficial das palavras, preso ao nível mais concreto da linguagem poética, a "melodia", estaria em 
perfeita consonância com seu contexto histórico. Este seria de incompletude, inacabamento, falta de rigor, em síntese: indefinição. Curiosamente, um momento histórico como este teria suas figuras típicas, o que é paradoxal. Apesar da falha na definição social, cultural e política, o período histórico estava então muito bem caracterizado na narrativa de Tristão de Athayde, uma vez que o fracasso não se deveria a qualquer tipo de indefinição por parte do autor, mas era atribuído à própria situação. Lendo este trecho podemos perceber que dar um nome não é simplesmente expressar alguma coisa já existente, mas delimitar, intervir, localizar. Por outro lado, afirmar de um período ou estilo que ele não tem nome, no âmbito da concepção de história pressuposta pelo autor, é forma bem explícita de se estabelecer uma definição. Não se trata, portanto, de simples negação, mas da atribuição afirmativa de algo que falta. Neste horizonte, dizer de um herói que ele não tem caráter era um modo bem preciso de caracterização.

Outro destes heróis supostamente típicos na sua indefinição, o poeta Raul de Leoni, seduzido pela tradição greco-latina em pleno ano de 1922, teve parte de sua obra reeditada em $1961 .^{6}$ Nesta edição, os poemas do autor vieram acompanhados de uma fortuna crítica. Em texto nela incluído, o mesmo Tristão de Athayde o situara como "a voz talvez mais autorizada de todo um estado de espírito coletivo, quando a nossa literatura parecia isolar-se inteiramente, tornar-se incomunicável à grande massa e à grande realidade brasileira"7 . A indefinição era então explicitamente relacionada a uma forma específica de alienação, a separação entre consciência e realidade nacional. Mas esta edição veio aqui à tona por uma questão ainda mais relevante. Dirigida a estudantes, ela trazia um daqueles questionários que, lidos superficialmente, vinham de antemão com as respostas já dadas pelos professores. Algumas de suas perguntas, no entanto, podem nos conduzir ao embaraço historiográfico discutido, desde que nos esqueçamos das primeiras e automáticas respostas:

1. Viveu realmente Raul de Leoni, considerado poeta de fim-de-século, em época de absoluta disponibilidade de espírito? Ou a chamada Belle Époque não foi o laboratório de um dos lustros de séculos mais rudes e trágicos da história da civilização ocidental?

4. A que escola, movimento ou grupo de poetas se poderia enquadrar a obra poética de Raul de Leoni ou filiá-la? Teria sido o poeta de Luz Mediterrânea de todo diferente dos demais poetas de seu tempo, a ponto de não haver essa possibilidade, por mais remota, de enquadramento?

5. Antecipou Raul de Leoni de fato o movimento modernista, como há quem o diga? Não teria sido ao contrário apenas um poeta passadista? 
10. Foi acaso Raul de Leoni um pensador pagão? Ou um cristão, mas inconsciente de sua filiação cristã?

É evidente que os parâmetros estabelecidos levam a um estado de tensão o texto, movido pela necessidade de enquadramento histórico. Por outro lado, além dos possíveis estudantes, uma das vozes silenciadas pela armadura da edição é a da personagem chamada Raul de Leoni. Em texto sem data definida, "Marinetti. O homem do século XX”, o autor teria dito que "em essência, o homem não é passadista, nem futurista, é um triste eternista, sempre adaptado ao presente, no seu destino de grande trágico da dor universal, a passar pela ironia das eternas esfinges". Ao questionário que impunha o dilema, ou passadista ou modernista, o autor poderia ter respondido com um desconcertante nem modernista nem passadista. Mas para que seu ponto de vista seja considerado, ao invés de desqualificado como sintoma de descompasso com a realidade histórica, é preciso primeiro desfazer a trama que uniu de maneira tão densa realidade e consciência (nacional).

\section{Realidade e consciência (nacional). $O$ sentido do modernismo.}

Em 1940, Rosário Fusco publicou a versão mais próxima do que seria então o discurso oficial sobre a literatura, o livro Política e Letras. Em pleno Estado Novo, o escritor que estreara anos antes como poeta nas trilhas do modernismo em Minas Gerais, seria ainda responsável pela seção de história literária da revista Cultura Política, ${ }^{8}$ ali participando por vezes também como porta-voz de Getúlio Vargas, na seção "O Pensamento do Chefe de Governo".

Política e Letras era uma revisão da história da literatura no Brasil, abrangendo do romantismo aos anos 1930. No livro, Rosário Fusco retomava um tema que já se tornara lugar-comum no pensamento sobre o Brasil, o de que, ao menos até 1930, as idéias produzidas no país não tinham qualquer relação com a sua realidade. Segundo o autor, até a suposta revolução liderada por Vargas, os intelectuais do país viviam encantados com a mera aparência dos discursos europeus, em estado de permanente ilusão. Do ponto de vista político, isso surgia como um pendor para as utopias e para o liberalismo, para o desejo de construir a civilização, mas num país em que a população seria incivilizada, degradada moral e etnicamente. 
Segundo Rosário Fusco, a literatura passava pelo mesmo tipo de defasagem. Os escritores, apenas percebendo a beleza superficial das palavras, atraídos pela forma sem fundamento, sem perceber que a literatura deveria dizer algo sobre a realidade que a cercava. Ambas, literatura e política, não constituindo um enfrentamento com o real, mas sim uma sublimação. ${ }^{9}$ Ou seja: o autor atribuía a um tipo de falha o caráter ilusório do texto literário (quando, se pensarmos mais propriamente no conceito freudiano por ele usado, a sublimação seria o processo, por assim dizer, normal da criação artística).

De fato, aqui Rosário Fusco não dizia qualquer novidade. Tristão de Athayde, por exemplo, já vinha afirmando desde a década de 1920 que a literatura brasileira era, ou tinha sido, incapaz de dar um sentido à realidade nacional. Mas o próprio Rosário Fusco estava entre aqueles que consideraram Tristão ${ }^{10} \mathrm{o}$ crítico literário por excelência do Brasil de então, aquele que definira o sentido essencial da literatura brasileira e estabelecera o norte para a interpretação do modernismo (entendido pelos dois autores como síntese e sintoma maior do que seria a própria literatura brasileira moderna).

Em texto fundamental, publicado na já citada coletânea $\grave{A}$ Margem da história da República, Tristão de Athayde ${ }^{11}$ apresentou a seguinte tese: "O erro da boêmia literária depois de 1889, fugindo à ação social e política; o sacrifício de Raul Pompéia; artificialismo de nossas correntes literárias; a reação de Euclides da Cunha." Seu pressuposto era o de que a situação literária da América tinha como pano de fundo uma originalidade mal conquistada. $\mathrm{O}$ que se devia ao desencontro entre as expectativas européias com relação ao Novo Mundo e as necessidades deste. A Europa, em seu ponto de vista civilização cansada e decadente (para este tema Tristão de Athayde sugeria a leitura de Spengler), procurava a vitalidade americana, fosse na rude natureza do sul ou na ingenuidade do norte. Mas as Américas, afirmava o autor, precisavam de inteligência. Daí que o equívoco que ele dizia encontrar na ânsia por imitação se revelasse numa nova forma: os americanos, ao se enxergarem com as lentes estabelecidas pela combalida civilização européia, exaltavam seu primitivismo como fator cultural próprio. No ponto de vista de Tristão de Athayde, as Américas precisavam tomar posse de si mesmas a partir de uma orientação consciente.

O Brasil, no contexto americano, seria uma nacionalidade mal formada aliada ao acúmulo de equívocos interpretativos. A realidade seria então confusa, e a consciência mera projeção fantasiosa. Depois de estabelecer tais parâmetros, Tristão de Athayde passava para a síntese histórica, discutindo a Colônia e o "transplante" da Metrópole, o Império, como era de suposta consolidação nacional, mas marcada pelo artificialismo 
social e pela República, momento de desencontro fatal entre inteligência e realidade. Além do fato de esta síntese histórica não ser nada original naquele momento, interessa notar como a narrativa histórica de Tristão de Athayde criava um campo do possível no qual a literatura iria depois ser encaixada. A escrita da história não apenas era a descrição de um ambiente, mas normatizava a leitura dos textos literários, ao propor como horizonte de interpretação um contexto que se propunha anterior a toda leitura. ${ }^{12}$

Ainda segundo o autor, a geração republicana teria percebido os males do artificialismo social (principalmente a partir de Canudos), mas teria proposto como solução um novo artificialismo jurídico. Sintetizando, os intelectuais republicanos pretenderiam "curar com ficções os males que as ficções tinham provocado". Em contraste com a versão histórica apresentada como a própria realidade, ou profunda evolução vital indicada pelos fatos e pela cronologia, teríamos então uma tradição intelectual apegada à mentira. Mas, notava o autor, o espírito dos indivíduos seria reflexo do espírito de seu povo. Sendo a nação mal delineada, suas artes apenas poderiam ser mero jogo e artificialismo. Assim, em oposição à idéia de realidade, o autor manejava conceitos como "ficção" no seu sentido mais comum, de mentira, invencionice.

O republicanismo político, na tese de Tristão de Athayde, veio acompanhado pelo naturalismo nas letras. Mais uma vez, propondo-se o jogo especular que o título do artigo propunha, entre política e letras. Segundo o autor, o naturalismo fora apenas uma pretensa abolição do lirismo, em nome de uma verdade mentirosa. Em poesia, o equivalente do movimento republicano teria sido o parnasianismo, uma opção estética, nesta perspectiva, ainda mais alienada, uma vez que nem sequer movida pela vontade de se encontrar a realidade. Mas, prosseguia o autor, a República proclamada teria trazido grande ímpeto libertador para as letras nacionais, daí uma explosão de diversos projetos literários individuais. Mas essa variedade não indicaria opulência, e sim apatia e debilidade. O Brasil teria escritores pertencentes a todas as gerações, num indício da inexistência de um problema nacional que os conciliasse.

Comparando a literatura republicana com a imperial, Tristão observava que o romantismo fora a primeira "aspiração consciente de nossa unidade". Esta, a vantagem cultural do Império, num texto marcado pela idéia de que a formação da consciência nacional deveria ser a medida da estética. A literatura republicana oscilaria entre a verdade local, provincial e o cosmopolitismo, sendo ainda "sem Deus". Tristão de Athayde arrematava, expondo uma tese que faria época na crítica literária brasileira do 
século XX (sobretudo devido à sua reformulação por Antonio Candido): se não se resolvesse a partir de um projeto nacional, a literatura republicana iria ficar presa no dilema entre regionalismo e cosmopolitismo. O primeiro, entendido como emanação do telurismo local, raiz, separava-se do segundo, a ideologia ou o esforço intelectual civilizado.

Citando ainda como exemplo o caso de Machado de Assis e seu suposto absenteísmo político, Tristão apresentava a imagem de uma defasagem antes de tudo política para a literatura feita no Brasil. A geração seguinte a Machado teria se preocupado com temas sociais e políticos, mas se perdera na boêmia. A dualidade apresentada como regionalismo e cosmopolitismo, ou realidade e consciência, recebia assim outra configuração como trajetória de vida dos escritores. Além do caso já citado da alienação, suposta, de Machado de Assis, Tristão de Athayde apresentava ainda, como figuras antagônicas, Eduardo Prado e Raul Pompéia. Este, com todo seu esforço de compreensão da realidade, mal saía dos cenáculos e dos cafés, por isso ignorado pela elite política. Raul Pompéia, dizia o autor, sentia os erros da formação nacional, mas não sabia propor um diagnóstico. Eduardo Prado, por sua vez, entendera o problema da ilusão republicana, mas propusera soluções idealistas. De um lado, uma encarnação de uma realidade cega para si mesma, de outro a lucidez paga com a moeda da alienação. Neste quadro, Canudos emergia como "aviso tremendo", de uma realidade desgarrada ameaçando a unidade nacional.

"Política e Letras" foi publicado em 1924, e não incorporava os acontecimentos literários dos anos 1920. Anos mais tarde, porém, Tristão de Athayde manteria o mesmo tipo de enquadramento para a avaliação crítica daquela década. Assim, em texto publicado em 1930, em que o crítico analisava as poesias de Augusto Frederico Schmidt e Augusto Meyer, ${ }^{13}$ ele propunha uma nova síntese histórica, apresentando a imagem de um marasmo cultural que teria perdurado até 1918, seguido pela libertação de 1923, propiciada pela Semana de Arte Moderna, e concluído em 1928 como ano de definição de um "novo espírito" no modernismo.

As idéias gerais voltam a interessar. O universal preocupa mais do que local. O social mais do que o estético. A procura pela procura começa a fatigar. E o fruto dos abridores de picadas tende a amadurecer. Terá passado o instante dos vanguardistas? Conquistadas as primeiras posições, não terá chegado o momento da consolidação? Quebrados os preconceitos não se iniciará agora a justificação de novos conceitos? Passadas as pesquisas, as intenções, as teorias, as demolições, não irá começar agora o trabalho da seleção entre as palavras e as obras? O inconsciente criador só se põe em movimento, depois de longo esforço de consciência. ${ }^{14}$ 
A Semana de Arte Moderna era então descrita como momento propício à retomada da procura consciente pela realidade nacional. Depois da franca alienação, do tatear errático de escritores presos aos seus projetos individuais, a expressão de um querer coletivo rumo à apropriação da totalidade da nação. O resultado teria sido ainda uma série de projetos diferentes, mas todos unidos pela necessidade de pesquisa consciente da realidade. Mais do àqueles projetos, o termo modernismo no significado estabelecido por Tristão de Athayde correspondia à dita necessidade. Este passo é importante, porque como se tornaria comum na historiografia do "modernismo" o termo era usado para domar a pluralidade de projetos estético-políticos dos anos 1920. Mas, prosseguia Tristão, em 1928 a procura consciente se tornara tão vital a ponto de se confundir com as dimensões inconscientes do corpo da nação. O modernismo tomava um novo rumo, ao ser pensado como o próprio instinto nacional expresso esteticamente. Aqui, era como se a inteligência e a realidade tivessem se tornado tão íntimas a ponto de se tornarem uma coisa única. ${ }^{15}$

Se um livro em particular foi apresentado por Tristão de Athayde como concretização desta realidade incorporada pelo discurso ficcional, este foi A Bagaceira, de José Américo de Almeida ${ }^{16}$ - que mais tarde seria canonizado como marco histórico de eclosão do novo "regionalismo" consolidado após a Revolução de 1930.

\footnotetext{
Quanto é possível exprimir o 'horror da realidade', - esse romance o exprimiu de uma maneira impressionante. Há, portanto, nesse livro a síntese em que eu vejo o que já pode haver de realmente nosso, de realmente novo em nossa arte literária: a inteligência e o instinto, a natureza bárbara da terra e dos homens do interior da terra, - e a natureza civilizada requintada do espírito que vai transformando essa terra, que se vai fundindo com ela e transfigurando-a para uma unidade futura. ${ }^{17}$
}

A síntese histórica aqui apresentada surgiu de várias formas nas críticas de Tristão. Mas a mais impressionante, por jogar com imagens que expressaram de modo inequívoco que a consciência estética delineada pelo autor era mais uma arma na estratégia de intervenção no campo do poder propriamente dito do que a projeção de um desejo de conhecimento, é a que ele inventou para tratar das obras de Mário de Andrade e Antônio de Alcântara Machado. ${ }^{18}$ No texto, o crítico falou que a realidade tinha sido apropriada pela nação, recorrendo à imagem de um movimento em forma de grandes círculos concêntricos.

Os três círculos desta tomada de posse seriam o americanismo, o brasileirismo e o regionalismo. O primeiro teria emergido com a simples noção do continente 
americano, do novo hemisfério, sua flora, sua fauna, seus indígenas. O brasileirismo, por sua vez, surgira como a consciência da nação incipiente, querendo (a nação) emancipar-se intelectualmente, como o fizera politicamente, e criando com isso o romance brasileiro, o poema brasileiro. E teríamos finalmente a inserção na realidade local e, portanto, no realismo regional, na expressão da fala provinciana, do tipo sertanejo, "do meio acanhado em sua originalidade delimitada geograficamente".

O movimento circular era então movido por uma finalidade, e não mero conjunto de acidentes históricos. A circularidade implicava ainda a idéia de um movimento racional, ordenado, não caótico. Em meio a esta rede metafórica, um lugarcomum, que hoje causa perplexidade, aparecia de modo quase natural. A nação recebia atributos de um sujeito, com todas as dimensões implicadas na psicologia aqui pressuposta por Tristão de Athayde. Um corpo, movido por desejos e marcado por seu desenho fisiológico, habitado por um dom espiritual, capaz de escolher seu destino, dotado de vontade. A consciência como resultante de um processo em que o sujeitonação tomava posse de si mesmo, ou seja, passava a viver e pensar com uma personalidade.

Mas não ficava nisso a metáfora apresentada por Tristão. O autor mesmo indicaria que o movimento circular era feito por um ser ativo, vivo, recorrendo à figura de um grande pássaro que procurava ou a sua presa ou o seu pouso, e que vinha descendo em círculos cada vez mais estreitos, numa espiral que acabava tocando a terra. Mas nada como as palavras do autor para explicitar os significados aqui discutidos.

Pois bem, o que a nova geração está criando, na mais original talvez de suas correntes, é mais um passo adiante. É como se o pássaro, depois de feito o ninho, começasse a explorar a terra, a se alimentar dela, a beber de suas águas, a viver nela e não mais sobre ela. Depois da inserção a apropriação: e, portanto, mais um passo adiante do regionalismo. Depois da necessidade consciente de uma alma nova, a própria inconsciência da nova alma: e, portanto, duas etapas mais, para além do brasileirismo. E nisso está, a meu ver, a grande força do novo movimento. O que realmente lhe é próprio. E representa um elo de evolução irresistível. Cada um segue a sua fórmula individual, naturalmente. Não creio, de modo nenhum, que seja o meio que faça o artista. Mas há um elemento de vitalidade subconsciente, aquilo que Butler chamava a memória da raça, e que cria as raízes do espírito na terra e que distingue justamente o que é simples arbítrio subjetivo do que é necessidade orgânica também. E o que se nota nestes dois livros, como em toda essa face do movimento moderno, é que o que era desejado e local, está passando a ser instintivo e nacional.

O que importa, no âmbito deste artigo, é perceber que a noção de realidade aplicada à literatura por críticos como Rosário Fusco e Tristão de Atahyde tinha ressonância num vocabulário mais abrangente, uma vez que a noção de real, necessariamente, tinha conotações sociais e políticas. A literatura seria então apenas 
uma faceta de uma sociedade incapaz de dizer o seu real, ao menos até 1922, 1928 ou 1930. Incapacidade tratada numa leitura de cunho também psicologizante e ao mesmo tempo metafísico, no sentido de que a realidade não seria percebida devido à suposta ausência de "consciência nacional". O termo consciência duplamente carregado, oscilando entre a filosofia da história de tipo hegeliano em que a consciência corresponderia à marcha do espírito humano rumo ao autoconhecimento, e à psicologia que se apresentava como ciência capaz de descobrir os modos como um corpo tomava posse de sua própria existência. Daí o recurso a termos como sublimação, alienação etc. O que ainda indica que a concepção de realidade destes autores não passava ao largo de discussões sobre o estatuto da subjetividade. Os dois escritores afirmavam-se como não materialistas, contrários à reprodução mecânica e artificial dos dados do real, inscrevendo a estética no ponto de encontro entre espiritualidade e mundo concreto.

Rosário Fusco, porém, traria mais uma contribuição ao debate, após dizer mais uma vez que em 1922 um movimento iniciara a tarefa da desalienação nacional, embora, em seu ponto de vista, em atitude excessivamente iconoclasta. $\mathrm{O}$ fato é que, de acordo com Rosário Fusco, a revolução modernista trouxera à baila a necessidade de que a literatura brasileira se abrisse para as demandas do real. Ainda segundo o autor, tais demandas ganhariam contornos nítidos, num processo de conscientização nacional, a partir da revolução política de 1930. Isso se deveria principalmente à "monstruosa genialidade" Vargas, que teria dado voz plena aos desejos populares antes apenas instintivos, dispersos, inconscientes. Com a ação de Vargas, o primeiro modernismo libertador fora substituído por outro.

\begin{abstract}
A revolução política assinalou, portanto, uma trégua na revolução literária. Normalizada a situação do país, verificou-se nas letras uma espécie de balanço correspondente àquele que a revolução impusera à sociedade e às instituições nacionais. E a depuração se fez, nas letras como na política, corrigindo os erros cometidos nos primeiros momentos em nome do entusiasmo da vitória obtida. Verificou-se que era preciso moderar a fúria inicial, durante tanto tempo sustentada contra tudo e contra todos. De outra, constatou-se que o caminho a percorrer era diverso e não aquele que vínhamos trilhando, com tanta pressa, sem atentarmos, convenientemente, para as pedras que havia no caminho. E começamos um segundo modernismo, mais espontâneo do que o primeiro, valendo-nos das lições que a experiência dele nos deixara. ${ }^{19}$
\end{abstract}

Efeito da ação estatal, que criara condições materiais para a visão adequada da realidade nacional, o modernismo em sua segunda fase se tornara menos destruidor, mais construtivo. A idéia antes esboçada por Tristão de Athayde de um modernismo instintivo depois de 1928, tornado corpo e consciência da nação, era diretamente 
associada ao Estado em Rosário Fusco. Daí, segundo o autor, o fato de a poética dos anos 1930 não se pautar por escolas ou movimentos, sendo a própria expressão da realidade, como o já citado romance de José Américo de Almeida. Ainda segundo Rosário Fusco, o Estado garantia a cada autor, individualmente, a livre expressão de sua sensibilidade, além de sustentar a possibilidade da observação direta da realidade, sem as ilusões que teriam marcado o romantismo, as utopias e o liberalismo. Mas a inflexão entre a versão estadonovista de Rosário Fusco e a de Tristão de Athayde, não deve ser pensada como "politização". E isso porque o mesmo Tristão estabelecera os pilares para a leitura do modernismo como síntese estético-política da nação.

De acordo com Rosário Fusco, os escritores dos anos 1930 não teriam opções literário-partidárias porque sua escola era a própria realidade. Aliado a isso, o condutor das massas Getúlio Vargas, futuro membro da Academia Brasileira de Letras, dava aos intelectuais o mais efetivo apoio no sentido profissional. Prova disso, ainda segundo Fusco, era a explosão do mercado editorial, com a emergência das grandes editoras. ${ }^{20}$ Dado que ele confirmaria ao apresentar uma imensa lista dos escritores dos anos 1930, todos unidos sob a égide do real nacional tornado consciente pela ação estatal: Jorge Amado, Graciliano Ramos, José Lins do Rego, Afonso Arinos, Hélio Viana, Cassiano Ricardo, Mário de Andrade, Josué de Castro, o próprio Getúlio Vargas, entre outros. Mais do que qualquer outro exemplo, esta lista de autores com projetos heterogêneos, e mesmo incompatíveis, deixa claro o potencial reducionismo contido no termo "modernismo", visto sob o prisma das relações entre realidade e consciência nacional.

A evidência da maturidade definitiva da dita consciência nacional era, segundo Fusco, a proliferação de livros, de discursos, enfim: a produtividade cultural do Estado liderado por Vargas. Produtividade inegável, a história da política cultural varguista já é bastante estudada pela historiografia. Mas se pensarmos que o que se produzia era a versão avassaladora de uma realidade política a partir da junção de propostas de cunho pedagógico com a propaganda estatal, além do recurso ao terror como instrumento de negação da pluralidade, ${ }^{21}$ concluiremos que os termos apresentados por Fusco têm sua razão de ser. Mas devem ser lidos ao avesso. Não que o Estado fosse a encarnação da consciência que tomava posse da realidade nacional, mas, ao contrário, que as ações estatais visassem ao controle da realidade a partir do estabelecimento da consciência nacional como horizonte último do que podia ser considerado "razoável" nos discursos.

O segundo modernismo era então descrito como a eclosão da realidade nacional na literatura graças à permissão governamental, ao ambiente de liberdade e segurança 
reinante no país de 1930. Por isso, num momento de "reconciliação do pensamento com a vida", o realismo teria se tornado lema político e literário. Como complemento à propalada visão realista de $\operatorname{Vargas}^{22}$ sobre as coisas do Brasil, a realidade se descortinava para os discursos literários. Esta relação foi explicitada pelo próprio Rosário Fusco em outros textos, como "A Cultura e a Vida", na seção de Cultura Política dedicada ao pensamento do "chefe de governo". ${ }^{23}$

No artigo, o crítico amparou sua proposta numa posição filosófica que determinava o real como sendo o histórico, o tempo dos acontecimentos, mas não no sentido de eventos que revelassem a espontaneidade da ação humana, mas como irrupção de forças instintivas e desejos presentes numa sociedade, como processo. Mas, ainda segundo o autor, a cultura não necessariamente daria um sentido a tais aspirações inconscientes - o caso do Brasil demonstraria a possibilidade contrária, de um total divórcio entre a realidade e o significado dos discursos. Ou seja: a cultura poderia se tornar meramente parasitária, não funcionando como consciência social ou nacional. Neste horizonte, a ação revolucionária de Vargas trouxera como novidade a união entre o "homem da cultura" e o "homem real".

$\mathrm{Na}$ tessitura narrativa de Rosário Fusco teríamos então uma história de torpor e inconsciência, seguida pelo choque liberador do modernismo, complementado no sentido da conscientização da realidade pela obra de Getúlio Vargas. No mesmo texto, o crítico literário deixou bem claro qual o fundamento mais concreto da emergência do real: a "autêntica garantia de nossa segurança." A consciência, fruto da observação e da atribuição correta de significados para a experiência, seria incompatível com o caos, a desordem ou o medo. E aqui se observe que a psicologização caminhava novamente no sentido do postulado da equivalência entre o indivíduo e a coletividade. Os mesmos termos aplicados à biografia pessoal serviam para a história da nação. Como uma pessoa, uma nação precisaria de tranqüilidade para se tornar madura, autoconsciente.

A maturidade da nação viera com a aparição de uma cultura que funcionava como sua consciência, esta elaborada pela coletividade dos intelectuais. De acordo com um dos vários editoriais de Cultura Política, demonstração disso era a colaboração espontânea de escritores das mais diversas opiniões políticas nas páginas da revista. $\mathrm{O}$ ambiente de segurança e ordem trazido por Vargas fizera com que os escritores se sentissem participantes da aventura de total desvelamento da realidade antes recalcada. Nas palavras da revista, a política tinha posto "o homem da inteligência no seu devido lugar." 24 
Hoje, felizmente, de tal modo o trabalhador intelectual se ajusta às diretrizes da nova ordem política do Brasil, que o que faz, o que projeta ou o que, realmente, realiza, é sempre um prolongamento da vontade do Estado, porque a vontade do Estado é a vontade do povo. ${ }^{25}$

A cultura era portanto pensada como consciência no sentido de "autoconhecimento" da força social e "ciência" de suas possibilidades. A exata observação da realidade, sem mediações fictícias, dava à nação a "posse de si mesma", numa expressão comum ao vocabulário político da época. Ou seja: saber o real tinha o efeito de controle sobre o destino, soberania política, e neste sentido liberdade - ao menos num discurso que equacionava liberdade a conhecimento. Mais tarde, Rosário Fusco diria que, dadas tais premissas, o líder político era um "profeta de realidades", ${ }^{26}$ alguém que sabia sentir os desejos latentes das massas e lhes dava uma forma visível mediante a determinação da ordem social. Por outro lado, que outra coisa faria um escritor, consciente de seu dever? Daí que, numa frase talvez crua, mas certamente impactante, de outro editorial da revista: "Ninguém é obrigado a escrever, mas todos escrevem". ${ }^{27}$ Assim, a realidade se convertia em tema obrigatório. Mas é claro: tratavase do real apresentado pela consciência nacional-estatal, e não de uma realidade que pudesse fugir ao controle.

A elaboração do significado da realidade para a consciência sempre trazia um perigo. A própria dificuldade em se estabelecer uma distinção clara entre o que seria ou não de acordo com a realidade da nação possibilitava o surgimento de interpretações conflitantes. Nas palavras de Rosário Fusco:

O traço fundamental de tudo que existe é a particularidade de um destino especial para cada ser. Por isso, a cada modo de existência corresponde um modo de vida. Mas somente ao homem cabe, no concerto das criaturas, a faculdade de assistir ao seu próprio destino. Eis porque só o homem possui problemas, só o homem reconhece o tempo, só homem trai. ${ }^{28}$

O perigo para a "consciência" e sua "realidade" conquistada era a própria espontaneidade do discurso e da ação política. Talvez por isso nos textos de Cultura Política, bem como em outros discursos de uma época em que o realismo se tornou verdadeira obsessão, a palavra "realidade" raramente vinha sem a companhia de algum qualificativo. Fosse social, nacional ou histórica, a realidade não era tratada apenas como a presença nua das coisas, ou como os eventos imprevisíveis da ação. Social, a realidade era aquela que obedecia a uma lógica desvendada pela ciência (aliás, num lapso bastante sugestivo, Azevedo Amaral, outro ideólogo do regime estadonovista, 
falara em "realidade sociológica"). Histórica, estava presa nas teias de uma filosofia evolucionista, que acreditava num processo hegeliano de conscientização. Nacional, fundava-se nos lugares-comuns sobre a nação, como sua suposta mistura de raças ou sua natureza tropical. Tudo convergindo para uma realidade já construída de antemão por algum logos que a literatura se limitaria a mimetizar.

A realidade não era apenas aquilo que o Estado tornara visível, era aquilo que o Estado deixava ver. O imperativo, implícito nas falas de Fusco: fale qualquer coisa, mas fale sobre a realidade, não era o mesmo que simplesmente: fale qualquer coisa. E era por meio desse mecanismo que essa mesma realidade, constituída por um logos consciente e soberano, fazia o milagre do congraçamento entre Graciliano Ramos e Plínio Salgado, Jorge Amado e Cassiano Ricardo, José Lins do Rego e Oswald de Andrade. Afinal, na segunda fase do modernismo teríamos apenas diferentes versões sobre a mesma realidade, depois que esta foi posta a público pela iconoclastia de $1922 \mathrm{e}$ pelo bom senso dos anos $1930 \ldots$ Com todas as diferenças e singularidades, todos os escritores se encontrariam nesta última fonte de sentido: a realidade nacional. Àqueles que, por alguma razão, não pudessem ter seu discurso recoberto por esta rede conceitual estava reservado o espaço da alienação.

Leve-se em consideração, ainda, que a crítica de Rosário Fusco não estabelecia parâmetros claros para a criação literária, mas visava a formação de um tipo de leitor. A questão não era tanto a de se imporem normas para a escrita (em casos extremos, a censura estava em ação, mas muitos relatos da época sugerem que os escritores desfrutavam de certa liberdade de criação...), quanto ensinar a ler. "Ler", no caso, seria procurar em romances ou poesias a parcela de realidade que lhes coubesse. Assim, não era preciso proibir a circulação dos livros de um autor como Graciliano Ramos, bastava ensinar ao leitor que eles discutiam uma realidade social degradada pelo atraso ou pelas intempéries naturais. Num horizonte de leitura assim dirigido, falar sobre a miséria social do sertão não constituía uma ameaça, uma vez que teria sido o próprio Estado quem começara a descer aos porões da realidade nacional. Ou, discutindo os desmandos de "coronéis", o mesmo Graciliano Ramos poderia estar apenas descrevendo um problema histórico do Brasil, o das oligarquias em fase de superação. Ou Dyonélio Machado, em O louco do Cati, tratando romanescamente de um caso já previsto pela criminologia.

A "realidade" cultural dos anos 1920 a 1940 foi inventada para ocultar os conflitos da política, seu radical e constitutivo desentendimento. Quanto a nós, leitores 
educados na idéia de que 1922 e 1930 são datas fundadoras da literatura nacional, ou na tese de que todos os escritores daqueles anos eram modernistas, de primeira ou segunda fase, apenas nos damos conta de que algo ficou fora do "real" quando nos lembramos de que a segurança garantida pela revolução (ou golpe, a relação entre termos e referentes em política nunca é estável...) foi obtida pela perpetração do terror estatal. A ordem social, confundida com a própria realidade a ser representada nos textos literários, era constantemente forjada pelo policiamento da política, pelo recurso à violência como argumento inescapável do Estado. Ou, numa via mais pacífica, pelos instrumentos pedagógicos eleitos para a consecução da ordem social (entre os quais, estava a literatura...).

O terror não é a tentativa de destruição de tudo aquilo que foge ao controle dos "profetas da realidade"? Uma forma de limitar o real aos imperativos do possível, este decidido pela ciência e pela voz genial do chefe de governo? Por outro lado, o real do terror não pode ser mais semelhante ao mundo alucinado que nós encontramos no porão do Navio Manaus? Seu narrador não pode aparecer como um tipo de consciência dilacerada, alienada? Pode ser denominado como "realidade" um mundo que perdeu seu $\log o s ?$

\section{Versões em conflito: idéias de consciência nos anos 1930}

Uma das características da vida intelectual dos anos 1930 e 1940 é a centralidade do discurso psicológico. Mário de Andrade, ${ }^{29}$ Tristão de Athayde, Rosário Fusco, Cassiano Ricardo, Francisco Campos, entre outros, definiam a psicologia como chave de interpretação para a sociedade, a cultura, a política. Tristão de Athayde, por exemplo, afirmara em texto analisado na seção anterior deste artigo, que estética e psicologia estavam no mesmo plano de conhecimento, no sentido de que ambas procuravam expressar e compreender a verdade constitutiva da subjetividade.

Não foi mera coincidência, portanto, o fato de o maior sucesso editorial de Tristão de Athayde nos anos 1930 ter sido um tratado de psicologia, Idade, Sexo e Tempo. ${ }^{30}$ Livro que apresentava os três temas indicados no título como se eles configurassem, em conjunto, uma tipologia da personalidade "normal". Na parte sobre a questão da idade, da infância à velhice, cada período da vida se delimitaria por suas paixões específicas, sua razão de ser, sua funcionalidade na constituição da pessoa. A discussão sobre o sexo apresentava-se como a já tradicional distribuição das tarefas de 
homens e mulheres, supostamente adaptadas às verdades profundas de cada gênero. $\mathrm{Na}$ parte sobre o tempo, o autor apresentou a personalidade dividida em duas diretrizes, a modernidade, no sentido do contingencial e atual, e a eternidade, a dimensão humana de criatura em busca da Salvação.

O autor chamou a atenção para o fato de seu personagem corresponder mais a um tipo psicológico genérico do que a encarnações singulares de pessoas. Mas o tempo todo, este mesmo tipo genérico funcionava em seu discurso como medida de normalidade, afastar-se dele seria se distanciar da verdade psicológica da natureza humana. Mais especificamente no que concerne ao tema deste artigo, o "sol da consciência" ${ }^{31}$ estaria já plenamente formado na mocidade (fase que duraria entre os 18 e os 35 anos de idade), mas ainda num embate com as paixões, a força máxima da vitalidade instintiva e jovem. Desse embate, nasceria a maturidade como fase de reconhecimento definitivo dos limites do real, de abandono dos delírios românticos da juventude. Maturidade que seria, segundo o autor, período realista por excelência, em dois sentidos: no do conhecimento sensato do mundo e no da projeção racional de obras (fossem políticas, culturais ou sociais) que se destinariam a fazer do mesmo a morada adequada à natureza humana. Politicamente, a mocidade se devotaria à agitação, aos devaneios revolucionários, à afirmação confiante das verdades absolutas, ao passo que a maturidade seria o momento de conformação ao real.

O quadro da normalidade desenhado por Tristão, porém, não vinha sem uma crítica ao mundo moderno, e, por conseguinte, ao Brasil contemporâneo. Esta se consubstanciava na afirmação de que a modernidade elegera o novo como valor absoluto, construindo o culto à mocidade como expressão de vida no mundanismo ateu (uma vez que a juventude seria a idade, por natureza, vitalista). Ou seja: o realismo da maturidade perdia seu poder de fecundar o mundo com criações objetivas no mundo moderno, degenerando-se em desilusão cínica, comodismo, após a fase dos desregramentos juvenis. A vida, aqui ocupando o mesmo espaço semântico da idéia de realidade, mais uma vez se divorciava da consciência, com a deturpação das idades naturais do homem na caótica vida moderna. Assim, mais que um retrato da psicologia humana normal, o livro de Tristão de Athayde visava à intervenção num mundo cultural e político que, segundo o autor, perdera os alicerces.

A verdade psicológica do realismo, portanto, colidia com a imagem de uma época de crise. Certamente, nos parâmetros do discurso do autor, era então necessária a montagem de estratégias de formação adequada da personalidade para a solução dos 
dilemas políticos do seu tempo. E, vale lembrar, este seria o território da estética e da psicologia, ambas portanto situadas num sentido pedagógico de conscientização. Pedagogia presente na própria tessitura da narrativa de Tristão de Athayde, resposta aos males do mundo que residia num tipo de texto que poderíamos indicar, não fosse o anacronismo, como de auto-ajuda. ${ }^{32}$

Era a partir de um aparato conceitual como o presente em Idade, Sexo e Tempo, por exemplo, que Rosário Fusco e Tristão de Athayde formularam imagens para os encontros e desencontros entre realidade e consciência, visando o estabelecimento de um sentido político e social para a literatura produzida no Brasil. Mas os autores não propuseram os termos como conceitos claramente delimitados, definidos teoricamente. Exemplo mais evidente de tentativa de definição foi o glossário apresentado em obra de Almir de Andrade, cuja apresentação aqui se faz necessária, ${ }^{33}$ porque ali mais claramente se estabeleceu o que se esperava que fosse compreendido quando outro alguém se deparasse com estes termos. Mas, além disso, por propor uma versão sintética em total consonância com as concepções presentes nos textos de crítica literária e psicologia de Tristão de Athayde e de Rosário Fusco. Recorde-se que Almir de Andrade era diretor da revista Cultura Política, e que portanto estamos diante de autores que participavam de um diálogo bastante intenso.

\footnotetext{
Real - Aquilo que é o que é, independentemente de qualquer conhecimento: precisamente aquilo que todo conhecimento se destina a alcançar.

Realidade - Qualidade do que é real. Conjunto de tudo o que é real.

Certeza - Acomodação natural da inteligência a uma verdade que já conquistou.

Consciência - Forma de atividade psíquica que traduz uma faculdade de representar o mundo sensível nos seus estados e nos seus movimentos.

Normal - Normal, para nós, é sempre um princípio de ordem e equilíbrio. Uma coisa ou um fato é normal, não por ser comum ou próprio da maioria, mas, tãosomente, por ser conforme às leis que o regem, estar perfeitamente adaptado à sua própria natureza.
}

Ou seja, o real seria o dado, aquilo que preexistiria a toda formulação. A consciência, conjunto de representações que teriam a finalidade de tornar esse mesmo real passível de ação e controle humanos. A normalidade não seria o comportamento comum, mas sim a adequação à verdade inscrita na natureza. A circularidade é por demais evidente, uma vez que não haveria conhecimento fora da dita consciência, e, ao mesmo tempo, a conformação à realidade seria a medida do sucesso ou fracasso de determinado aparelho psíquico. A eficácia social comprovaria a verdade da consciência, e esta se mediria pelo sucesso na adaptação à realidade. Neste caso, estética e psicologia reafirmavam certezas políticas. Menos do que de realidade e consciência, tratava-se do 
estabelecimento de significados que recobrissem as incertezas do mundo político com a solidez aparente de um real submetido à lógica discursiva do conhecimento. $\mathrm{O}$ modernismo, juntamente com o projeto político liderado por Getúlio Vargas, seria então o momento privilegiado de autoconhecimento nacional. Fora do modernismo, estaríamos fora da autoconsciência, imersos na alienação. Daí que a narrativa modernista distendesse o passado e o futuro, homogeneizando-os.

Dito isso, este artigo poderia ser considerado concluído. Porém, uma última incursão se faz necessária. Isso porque é muito comum em história das idéias o uso da imagem do contexto social e político como uma força determinante para a interpretação da relação entre os discursos e as experiências de um período. Assim, por exemplo, dadas as flagrantes coincidências entre o que os autores até aqui discutidos afirmaram, compondo-se uma rede conceitual mais ou menos fechada, poderíamos dizer que eles então apenas diziam o que era possível ser dito na sua época. O problema é que outras conceitualizações para as relações entre realidade e consciência estavam disponíveis no período. Portanto, mais do que suposta imposição de um vocabulário de época, estamos diante de escolhas.

Um encontro mais ou menos casual com o quase esquecido livro de Flavio de Carvalho $^{34}$ é a fonte mais direta deste questionamento final. Mas mais do que constatação metodológica, ou suposta teorização mais adequada, o texto de Flávio de Carvalho é sobretudo alegria para aqueles que ainda persistem no desafio de pensar a liberdade quando encontram, como Hannah Arendt certa vez sugeriu, uma personagem que, em ambiente de marcado conformismo, apresenta a face da singularidade e da espontaneidade. Isso por si só desafia aqueles que insistiram em limitar o real à coerência pressuposta no possível - mais pela diferença propriamente dita do que por um conteúdo mais afinado com as expectativas teóricas do historiador.

Trata-se de Experiência N. 2. Uma possível teoria e uma experiência, de 1931, livro inusitado sob vários aspectos. Nele, o autor relata e interpreta uma experiência por ele feita num dia de Corpus-Christi, quando desafiou uma procissão ao andar em sentido contrário a ela, munido de seu espalhafatoso boné verde, no intuito de "palpar psiquicamente a emoção tempestuosa da alma coletiva". Emoção tempestuosa que redundou num quase-linchamento, noticiado como pequeno escândalo nas páginas do Estado de S. Paulo.

Essa experiência, por si só insólita, teve ainda complemento numa teoria para as relações entre consciência e estética. Seguindo os passos de Freud, mais 
especificamente de Totem e Tabu, Flávio de Carvalho trataria a consciência, individual e coletiva (esta forjada nos ajuntamentos militares, nas procissões, nas pátrias), sob o prisma do "parâmetro da astúcia". Ser astucioso seria uma estratégia de sobrevivência, mas não no sentido passivo de adaptação à realidade dada, e sim no da tentativa de apropriação do mundo pelo complexo de onipotência que fundaria toda subjetividade. Num sentido bastante preciso, portanto, a consciência era, segundo Flávio de Carvalho, um instrumento de conquista. A realidade, efeito de um conflito que também resultava na associação de personalidades num corpo político autoritário, movido pelo mesmo complexo de onipotência. Ao enfrentarem suas limitações e fraquezas inevitáveis, as pessoas acabariam se acomodando em torno de objetos-fetiche que dariam a elas a ilusão apaziguadora do real como dado.

O livro tem ainda muitas questões que não cabem nos objetivos deste artigo. Por exemplo, compartilha com os outros autores discutidos uma constante depreciação do feminino como traço próprio do engodo, da sedução - apenas com o leve desvio no sentido de dizer que a virilidade do líder, do santo, do professor, do diplomata, também recorre aos mesmos artifícios "afeminados". E, o que é ainda mais relevante, está no mesmo terreno psicologizante dos outros livros. Mas sua noção de consciência tende a corroer a imagem do sujeito capaz de dizer o real. Por outro lado, o próprio narrador se lançou de corpo e alma na experiência, e o que ele afirmou sobre a procissão também valia para si mesmo. O rebaixamento da consciência na hierarquia da economia psíquica correspondia assim à relação de reciprocidade entre escritor e multidões, diferentemente do modernismo que pressupunha uma relação hierárquica entre escritores e sociedade. Ou, como diria Flávio de Carvalho, o processo de totemização tornaria simétrico aquilo que a consciência pretenderia deixar estabelecido como relação unilateral entre o poderoso sujeito consciente de si e a multidão de irracionais.

\footnotetext{
O contato com o mundo objetivo reaviva no sujeito uma série de associações, de ideais; ele se lembra do já vivido que de um certo modo, numa certa ordem, é a sua teoria sobre a vida. E ele maneja o mundo objetivo de acordo com essa teoria, perpetuando a rotina. A teoria é imposta ao sujeito pelo mundo objetivo, como condição de vida, e as suas associações são produzidas por autodefesa, para manter a ilusão de sua virilidade e evitar uma depreciação que resultaria, caso ele abandonasse a rotina. Repetindo a teoria ele se integra agradavelmente no ambiente estandartizado, é acolhido pelo inimigo como um igual pronto a ser devorado, e segue cordialmente o passo de reza da vida. A teoria que ele ostenta em defesa própria é a sua consciência, em função de um aglomerado heterogêneo de homens. Ela só pode sobreviver pela estandartização e pela afinidade geral para com ele. A base de toda a consciência é a defesa própria. Colocar-se em segurança, tem aceitação geral, e todas as vezes que pensamos "minha consciência me diz que devo fazer isto..." é para nos colocar em segurança com relação à rotina, não perder o prestígio de nossa personalidade, num movimento de astúcia para nos garantir no futuro. ${ }^{35}$
} 
FARIA, Daniel. Reality and national conscience. The political meaning of modernism. História, São Paulo, v. 26, n. 2, p. 384-404, 2007.

\begin{abstract}
This article has as thematic starting point a remark on a recurrent subject in the culture history of the First Republic: the supposed alienation of the intellectual elite. This image has had as counterpoint the concept of modernism, formulated by intellectuals as Tristão de Athayde and Rosário Fusco, which was based on the idea of a conscience that emerged from national reality. The parallelism of this speech with arguments used to give revolutionary legitimacy to the 1930's blow, however, discloses that the elaborated terms, at first sight aiming at a cultural project creation, were simultaneously an expression of political desires.
\end{abstract}

Keywords: modernism; realism; politics.

Artigo recebido em 07/2007. Aprovado em 08/2007.

\title{
NOTAS:
}

* Pós-doutorando em História, pela Unicamp. Este artigo faz parte de projeto financiado pela Fapesp.

${ }^{1}$ DEDECCA, Edgar. 1930: O Silêncio dos vencidos. São Paulo: Brasiliense, 1981. VESENTINI, Carlos Alberto. A teia do fato. Uma proposta de estudo sobre a memória histórica. São Paulo: Hucitec, 1997.

${ }^{2}$ Destaque-se que a abrangência do trabalho é maior, uma vez que diz respeito aos lugares-comuns encontrados na interpretação da suposta realidade nacional (BRESCIANI, Maria Stella Martins. $O$ charme da ciência e a sedução da objetividade: Oliveira Vianna entre intérpretes do Brasil. São Paulo: Editora da Unesp, 2005). Noutra perspectiva, Elizabeth Cancelli fez questionamentos instigantes e incisivos às versões predominantes sobre a relação entre idéias e política na Primeira República. Cf. $A$ cultura do crime e da lei. Brasília: EdUnB, 2001.

${ }^{3}$ Estes autores são citados apenas para indicar a recorrência do tema, não se faz aqui uma apreciação dos trabalhos, o que não caberia no âmbito deste artigo. Cf. CAMARGOS, Márcia. Villa Kyrial: crônica da Belle Époque paulistana. São Paulo: Senac, 2001; PRADO, Antonio Arnoni. Trincheira, palco e letras. São Paulo: Cosac Y Naif, 2004; NEEDELL, Jeffrey. Belle Époque Tropical. Sociedade e cultura de elite no Rio de Janeiro da virada do século. São Paulo: Companhia das Letras, 1993; CANDIDO, Antonio. Literatura e sociedade. Estudo de teoria e história literária. São Paulo: Compañía Editora Nacional, 1965; BROCA, Brito. “A Grécia no Brasil”. In A Vida Literária no Brasil-1900. Brasília: INL.

${ }^{4} \mathrm{O}$ nome pré-modernismo foi proposto por Tristão de Athayde, situado ambiguamente entre o quasemodernista e o ainda-não-modernista. O embaraço desta nomeação é parecido ao de títulos como préhistória ou pré-socráticos, pois todos nos remetem ao intricado terreno das origens. José Paulo Paes notou esta dificuldade, discutindo o problema no nível terminológico-taxonômico, em: O art nouveau na literatura brasileira. Gregos e baianos. São Paulo: Brasiliense, 1985, p. 64-80. Sua proposta, que inclui a definição de artenovismo em contraponto ao pré-modernismo, é sem dúvida esclarecedora sob vários aspectos, sobretudo pelo modo como o autor discute o tema do ornamental (longe do à primeira vista elogio do artifício como superfície enganadora, de acordo com o autor sua filosofia seria o vitalismo).

${ }^{5}$ Vozes de perto. Estudos. $5^{a}$ série. Rio de Janeiro: Civilização Brasileira, 1933. p. 113.

${ }^{6}$ LEONI, Raul de. Textos escolhidos. Rio de Janeiro: Agir, 1961.

${ }^{7}$ Idem, p. 122.

${ }^{8}$ Para uma percepção mais abrangente do projeto intelectual e político da publicação: VELLOSO, Mônica Pimenta. Cultura e poder político: uma configuração do campo intelectual. In: OLIVEIRA, Lúcia Lippi, VELLOSO, Mônica Pimenta e GOMES, Ângela Maria Castro. Estado Novo: Ideologia e poder. Rio de Janeiro: Zahar, 1982. p. 71-108. 
${ }^{9}$ Nas palavras do autor. Política e letras. Síntese das atividades literárias brasileiras no decênio 1930-
1940 . Rio de Janeiro: José Olympio, 1940. p. 51 .
${ }^{10}$ Nas palavras de Fusco, Tristão teria sido "o sistematizador do movimento modernista". Cf. FUSCO,
Rosário. Letras de 1938. Vida Literária. São Paulo: S. E. Panorama, 1940.
${ }^{11}$ Política e Letras. In CARDOSO, Vicente Licínio (org.). Á margem da história da República. Inquérito
por escritores da geração nascida com a República. $3^{\mathrm{a}}$ ed. Recife: Editora Massangana, 1990. p. 209-256.
Recorde-se que a primeira edição data de 1924 .
${ }^{12}$ A eleição do contexto como fonte última de todo significado foi alvo de crítica definitiva (LACAPRA,
Dominck. Rethinking intelectual history. Texts, contexts, language. Ithaca/New York: Cornell University Press, 1983).

${ }^{13}$ ATHAYDE, Tristão de. Dois poetas inquietos. Estudos. $3^{a}$ Série. Rio de Janeiro: A Ordem, 1930. p. 5671.

${ }^{14}$ Idem, p. 60.

${ }^{15}$ Note-se ainda que para o autor estética e psicologia pertenciam a um mesmo território de definição da realidade humana, aquele em que o homem se voltava sobre si mesmo.

16 "Uma revelação", crônica sobre a obra de José Américo de Almeida, em: Estudos $2^{a}$ Série. Rio de Janeiro: Terra de Sol, 1928. p. 139-151.

${ }^{17}$ Idem, p. 140.

${ }^{18}$ Em: Romancistas ao sul, Estudos $2^{a}$ Série. Op. cit., p. 24-36.

${ }^{19}$ Política e letras. Síntese das atividades literárias brasileiras no decênio 1930-1940. Op. cit., p. 135.

${ }^{20}$ Aqui o fundo de verdade era o controle exercido pelo Estado sobre a importação de papel, o que criava uma relação de dependência e troca de favores com as editoras, como a José Olympio que publicara o livro de Rosário Fusco.

${ }^{21}$ ARENDT, Hannah. A condição humana. Rio de Janeiro: Forense Universitária, 2001.

${ }^{22} \mathrm{O}$ realismo político de Vargas era tema recorrente na propaganda do regime, repetido à exaustão.

${ }^{23}$ Cultura Politica. Ano 1, n. 2, abril de 1941, p. 169-177.

${ }^{24}$ A ordem política e a evolução intelectual. In Cultura Política. Ano 1, n. 4, junho de 1941, p. 234.

${ }^{25}$ Idem, p. 234.

${ }^{26}$ História e passado. In Cultura Política, ano 1, n. 8, outubro de 1941.

${ }^{27}$ Influência da ordem política sobre a evolução intelectual. In: Cultura Política, ano 1, n. 10, dezembro de 1941, p. 312.

${ }^{28}$ Realismo e bom senso. In Cultura Política, ano 2, n. 15, maio de 1942, p. 99.

${ }^{29}$ Especialmente no que se refere às concepções estéticas de Mário de Andrade, esta questão foi apresentada por SCHWARZ, Roberto. O psicologismo da poética de Mário de Andrade. In A sereia e o desconfiado. Rio de Janeiro: Paz e Terra, 1981. p. 13-23.

${ }^{30}$ Este, publicado sem o pseudônimo: LIMA, Alceu Amoroso. Idade, sexo e tempo. Três aspectos da psicologia humana. Rio de Janeiro: José Olympio, 1938.

${ }_{31}^{31}$ Alceu Amoroso Lima. Idem, p. 103.

${ }^{32}$ Este significado se torna mais evidente se lermos, na contracapa do livro, anúncios de outras obras incluídas na mesma temática. J. Ralph, Conhece-te pela psicanálise, indicado como extremamente útil para a construção da vida harmoniosa pelo homem normal; L. E. Gratia, $O$ acanhamento e a timidez, com o seguinte lema: "Destrua tua timidez, e a vida será tua"; W. Steckel, A Educação dos pais, que vinha descrito como indicação de como os educadores deveriam se corrigir para poderem melhor educar as crianças, trazendo um verdadeiro panorama da normalidade sitiada por pais alcoólatras, anormais, egoístas, levianos, mães muito novas, mães "quarentonas", mães puritanas e crianças nervosas.

${ }_{33}$ ANDRADE, Almir de. Da interpretação na psicologia. Crítica aos fundamentos da psicologia contemporânea. Ensaio de reelaboração sistemática de uma psicologia dinâmica, como base de uma teoria do conhecimento. Rio de Janeiro: Livraria José Olympio, 1936.

${ }_{34}$ Mais ou menos casual, porque o livro teve apenas duas edições, num período de 70 anos (CARVALHO, Flavio de. Experiência n. 2. Uma possivel teoria e uma experiência. Rio de Janeiro: Nau Editora, 2001).

${ }^{35}$ Idem, p. 103-105. 